\title{
On Some Aspects of Process Management and Human Resource Management Interaction at the Customs Authorities
}

\author{
Mara Petersone, Karlis Ketners, Aivars Vilnis Krastins \\ Department of Customs and Taxes, International Business and Customs Institute, \\ Faculty of Engineering Economics and Management \\ Riga Technical University \\ Riga, Latvia
}

Received: May 28, 2019. Revised: September 17, 2 021. Accepted: October 10, 2021. Published: November $22,2021$.

\begin{abstract}
On some aspects of process management and human resource management interaction at the customs authorities". Main stakeholders such as European Commission Directorate-General Taxation and Customs Union, World Customs Organization, universities and world customs administrations are looking for better training support mechanism, how to create contact points for university and customs internal training and to create qualitative business training programs in the customs area. In spite of different activities, for the time being concise and clear mechanism does not exist. Another problem lies in condition that training requirements do not underlie processes and job descriptions. Training organizers - customs authorities training centers and universities, developing own training programs follow the goals and objectives of staff development strategy, it becomes apparent that interaction of job descriptions and occupation standards is relatively little and do not supplement each other. The aim of research is to describe the mechanism of existing and potential human resource management and process management mutual interaction and mutual influence. To achieve the goal there has been set a task to study the specifics of job description formation at customs authorities, describe the significance of occupation descriptions to provide work at customs and their legislation, analyze the role of occupation standards to provide training needs. As a result of research proposals have been submitted about the improvement of process management, job description and occupation standard mutual interaction mechanism. Research is based on comparative analysis of literature and practical experience of custom authorities.
\end{abstract}

Keywords - customs authorities, process management, job description, occupation standards.

\section{INTRODUCTION}

Human resources are one of the main factors necessary for every organization especially in public sector. To create environment where employee is capable and wants to act to achieve organization's goals and accordingly execute organization's mission and strategic goals. "The contemporary architecture of company processes allows more flexibility, however it is more demanding with respect to knowledge potential and empowerment of employees. However it remains extremely important how to grasp the formulated strategy, how to distribute it and integrate into company processes and how to ensure their synergies within the framework of existing managerial competencies."[1] One of the key requirements for good functioning and adequate compliance with assigned mission for Tax and Customs Administrations (TCA) is successful human resource management (HRM). Tax and Customs Administrations require clear rules and procedures, also rely heavily on IT infrastructure and processes, but also need motivated and well-trained Professional staff able to respond to the increasing complexity of laws and international agreements, the growing demand of the society in terms of providing adequate services and effective law enforcement. This focuses on the attention that should be given to the HRM and justifies the demand for professional qualifications, responsibility and reactivity that characterize the Tax and Customs Administrations. HRM is the linking pin between objectives, processes and measuring the results. If the objectives are not clearly communicated, understood and adopted by staff the results will be most likely be poor. One of main aspects of Tax and Customs Administrations' HRM seems to be training and development. The aim of implementing training and development is to make TCA staff more professional by means of a continuous and systematic training process that will increase their knowledge and abilities in order to contribute to rendering efficient services and guaranteeing achievement of goals and mission. Organizations are increasingly looking for staff that is able to perform more functions and that have high level of training. Training is evermore a permanent process of support, not only for learning better practices, but also for sustaining development, the administrative career, full exercise of competences of positions and a change of attitude. Thus it is very important to create a permanent link between processes and training.

"Education is a complex, dynamic and heterogeneous activity that can be evidenced in the multiple processes, phenomena and institutions worldwide that have agreed that "education" is not a simple discrimination between educational events or not, however it is possible to identify spaces for formal, non - formal and informal, where this tripartite covers the universe of educational processes of people. 
Despite of the various positions on the differentiation between formal, non - formal and in formal education, it can be understood the formal and non - formal as products of intentional and systematic processes." "All le arning activity undertaken throughout life, which results in improving knowledge, know- how, skills, competences and/or qualifications for personal, social and/or professional reasons." "Universities are participating in continuous education for society, however, there is currently a resizing university task proposing a "third university mission", which is the knowledge transfer and social responsibility, creating cooperative networks between social, economic, political and stakeholders, drawing up plans that provide different options, if possible, tailored to individual or group needs." [2]

"Higher Education is a key element in the golden triangle which also includes academic research and business community. The Lisbon strategy mentions that the universities must consider the employability of their graduates, equip them with the skills for public and private sectors, and ensure that the unemployed can improve their skills for work.'[3]

Regulatory framework - laws, international agreements and procedures is as a base for process management in customs and tax authorities. If in the scope of tax authorities national laws and regulations have great importance and which, influenced by historical, economical or legal factors, differs from country to country, then in the case of customs authorities the international agreements and other supranational regulations (such as for example The modernized Community Customs Code or Eurasian Customs Union Customs Code) have great importance. Thus, as a result of regulatory framework process management of customs authorities can be systematized and unified according to common principles and can serve as future example for process unification also for tax authorities. This can be a first step to more close integration of TCA officers and intraorganizational mobility. Other issue is personnel training organization which may be carried out by internal training centers within TCA (rather traditional approach) or licensed and accredited universities. Without further discussion about this aspect it should be noted that university training from a development perspective and inclusion into the labor market perspective has more advantages. Main stakeholders such as European Commission Directorate-General Taxation and Customs Union (EC DG TAXUD), World Customs Organization (WCO), universities and world customs administrations are looking for better training support mechanism, how to create contact points for university and customs internal training and to create qualitative business training programs in the customs area. In spite of different activities, for example WCO Partnerships in Customs Academic Research and Development program (PICARD) or European Commission supported Programs Information and Collaboration Space (PICS) [4] where professionals working in the field of customs and tax share information, materials and create joint projects, but TACTIC 2.0 formed on the basis of PICS which includes creation of joint training projects for the time being concise and clear mechanism does not exist. At the moment EC is developing a proficiency guidebook where positions shall be grouped starting from the highest, middlelevel managers and ending with ordinary workers' positions at the ports, airports and land. However, there is a great number of positions at customs authorities in EU member states, EU candidate countries and potential candidate countries. This activities allows to raise many issues - for example - according to what principle is it possible to group positions and moreover to make a proficiency list for every group of customs officers, and furthermore how shall this handbook interact with national, WCO or maybe internal occupation standards if such would be formed. For example, in 2002 Lithuanian customs was reported to have job descriptions of officers which include only general qualifications requirements, obligations, rights and responsibilities, there are no detailed knowledge and skills which are necessary for descriptions at every career stage of customs officer. Consequently, in Lithuania, according to the example of Italian customs, qualification requirements of officer were developed and fixed to career levels [5].

Another problem lies in condition that training requirements do not underlie business processes and job descriptions. Training organizers - customs authorities training centers and universities, developing own training programs follow the goals and objectives of staff development strategy, it becomes apparent that interaction of job descriptions and occupation standards is relatively little and do not supplement each other. Besides, development of occupation standards and changes in them take a long time and resources to provide current occupation standards continuously. Also it should be mentioned that as educational institution or organization is an open system. Open systems are complex systems which take information, material and energy from the external environment and transform these resources into knowledge, processes and structures that produce goods and services. Due to this, complex systems are usually out of balance: in spite of the seeming stability, the system is constantly changing. [6]

The aim of research is to describe the mechanism of existing and potential human resource management (HRM) and process management mutual interaction and mutual influence. To achieve the goal there has been set a task to study the specifics of job description formation at customs authorities, describe the significance of occupation descriptions to provide work at customs and their legislation, analyze the role of occupation standards to provide training needs. As a result of research proposals have been submitted about the improvement of process management, job description and occupation standard mutual interaction mechanism. Research is based on comparative analysis of literature and practical experience of custom authorities. Empiric research is substantiated by the open source information and statistical data of Latvian customs.

\section{PROCESS MANAGEMENT ADAPTATION POSSIBILITIES IN HUMAN RESOURCES MANAGEMENT AT THE CUSTOMS AUTHORITIES}

Authors believe that Latvian joint TCA - State Revenue Service (SRS), should be presented as a p ositive example regarding the improvement of institution work management, specifically creating job descriptions on the basis of process management system. (See Fig.1.) 


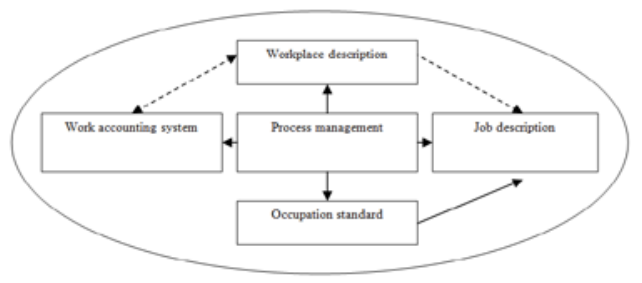

Fig.1.The principles of process management adaptation in human resource management at the customs authorities

Within the process management system it is possible to determine the quantitative indicator of process implementation, therefore, adjusting corresponding tools it is possible to precisely observe not only individual work but also the work amount of whole institution, objective mechanism develops knowing process costs. On this basis it is possible to evaluate the work of each employee and department so optimizing the work of institution as a whole. For example, SRS intended to improve and develop process management system in order to optimize departments and to account implementation costs, setting clearly defined goals, actions, outcome (outcomes) and fruitful indicators to each process and introducing accounting of all process implementation and costs [7]. As soon as quantitative indicators of work record system change, meaning, the amount of specific process implementation changes, the administration of customs authorities has the justification to make changes in the number of workplaces and thus possibly in descriptions of workplaces.

According to the image provided by the authors, in case of necessity to change processes it might be necessary to introduce changes in workplace descriptions while it may cause the necessity to change a certain number of job descriptions.

Internal documentation of institution in the area of human resources management should be structured according to the mutual compatibility principle, namely, if the processes are identified, process activities and sub-activities, process outcome (outcomes), fruitful indicators, for the implementation of each process there should be determined necessary knowledge, professional experience and skills which accordingly should be used in job descriptions and occupation standards. Depending on occupation standard it is possible to identify the level of necessary occupation and education for each workplace.

As shown in Tab. 1 since 2000 SRS as public agency is focused on formal educational needs and higher education delivery from universities. In 2000 only $43 \%$ of SRS employees had Graduate Diplomas but in 2012 already 93\% notwithstanding of the decrease of number of employees due to public finance crisis. As from 1994 Riga Technical University is delivering providing training programs at a BA and MA level. This programs are accredited according to World Customs organization Curricula and professional standards

\section{TABLE I.}

\begin{tabular}{|l|l|l|l|l|}
\hline \multirow{2}{*}{ Staff } & \multicolumn{4}{|c|}{ Year } \\
\cline { 2 - 5 } & $\mathbf{2 0 0 0}$ & $\mathbf{2 0 0 5}$ & $\mathbf{2 0 1 0}$ & $\mathbf{2 0 1 2}$ \\
\hline $\begin{array}{l}\text { SRS } \\
\text { employees }\end{array}$ & 4676 & 5019 & 4176 & 4069 \\
\hline $\begin{array}{l}\text { Higher } \\
\text { education }\end{array}$ & 2106 & 4617 & 3883 & 3784 \\
\hline
\end{tabular}

On the basis of Latvian education system common European system of training could be created. Core European Curricula and core competency framework for customs is critical to enabling coordination and harmonization of the competences and standards across the customs profession. Mainly educational standards for higher education should be developed for EQF level 7 (MA level) which targets broader strategic and managerial knowledge. This level is also critical to innovation and research as it would provide both professional and scientific courses which include skill specializations and customs knowledge. Some training needs are satisfied with training courses. As for 2010 SRS employees participated in 4799 training events, but average training duration was 7.5 hours per employees. As for 2011 there was 5353 seminars and courses and average training duration was 8.8 hours. According to evaluation research $77 \%$ of employees was satisfied with training quality. The SRS statistics in 2012 shows increase in trained persons by $44 \%$, but at the same time average training duration decreased and was as 6,67 hours. This shows instability in internal and external training courses and seminars and leads to the necessity of standardization of training on the basis of job descriptions and occupational standards. [8]

\section{SIGNIFICANCE OF JOB DESCRIPTIONS TO SECURE CUSTOMS WORK}

Job description means that a job has been assessed not the person to whom description has been given, what should the person be like working in the corresponding position and what should the person do. Job description in fact is a document describing job content. Only after the employee and the person in charge from the institution have signed the job description it may be considered as an agreement about the job content between employee and employer.

Job description should include:

- $\quad$ professional responsibilities required to do the job;

- range of issues that must be known to do the specific job-required vocational education, professional experience and skills;

- $\quad$ rights and responsibility for the process and results;

- job subordination and cooperation necessary to do the job;

- job position according to the job classification system;

- $\quad$ physical requirements necessary for doing specific job;

- $\quad$ special work conditions. 
It is advisable to arrange responsibilities in job description in order of implementation as this is how the responsibilities are obvious and comparable to other job descriptions. J ob description is a legislative text with its stylistic peculiarity, which is described by formality, precise and clear definitions, plain and consistently used terms and possibly short and brief expression.

It is possible to make qualitative job description only if all the professional responsibilities necessary to do the job, which result from goals and objectives of institution, have been described. Rights and responsibilities reviewed in job description about the process and results emerge from laws and regulations according to which employees of corresponding institution or company act. Job subordination and cooperation necessary to do the job are like the result of professional responsibilities necessary to do the job.

On preparing job descriptions the following considerations must be taken into account:

- nature of the work must correspond and agree with business processes, it means with the goals and objectives of an institution;

- job descriptions should be as standardized as possible;

- line manager has to participate in creation of job description or has to be informed about its content.

Traditionally it has been accepted that job description helps in job organization and management, job assessment, employee recruitment and training. Human resource management experts and mangers try to obtain that everything written in job description should be measured. Recruiting employees on the basis of such "measurable" job description employer cannot be subjective but objective. Given such a "measurable" job description it is possible for an employer to compare if the respective employee works as much as another employee who does the same job. Analyzing job descriptions it is possible to find out which employee needs the training and what kind, thus creating training programs it is necessary to formulate what the student will know and be able to do after finishing studies which also is a measurable thing.

The authors believe that only in case job descriptions are made based on process management system it is possible to gain measurable and comparable results selecting, training and evaluating employees. Thus changing the process job description will change that will indicate on the employee whose job responsibilities will change and who will need additionally to learn innovations, to evaluate if the employee corresponds to the job description and if there will be necessity to recruit new employees.

In Latvian SRS customs authorities job description of field customs officer is the sum of those workplace descriptions where the employee can work, theoretically it comes out that the higher the position the more there are equal work places, thus there is less need for the customs officer to work in different work places it means that the job description will be with little range of responsibilities and vice versa the lower the position the more there will be work places where it will be necessary for one employee to work and thus range of responsibilities reviewed in job descriptions will be much wider it may be even said that the customs officer will be more "universal", for example in Latvia at the small customs post "Vientuli" in different seasons and times of day customs responsibilities can be done by only one official who will work in more work places and will be on shift assignment basis. Making job descriptions, which are made on the basis of processes and process activities, several job descriptions can be described as standard ones.

Two types of job descriptions are distinguished in Latviaofficer and employee job description. Job description of officer is a document which defines job title, position in the framework of institution, obligations, rights, responsibilities and requirements necessary to do the job. For the civil service job description is obligatory [9] but the labor law [10] does not stipulate job description as obligation. At the moment in Latvia state and municipality institutions the content of job description is regulated by "Officer job description development procedure". Job description should specify the title of institution, the title of department, the title of officer's job and the category of job qualification, the subordination of officer's job, job responsibilities, job rights, education necessary to do the job, professional experience necessary to do the job, cooperation necessary to do the job and responsibility for the work process and results[11]. While in other normative document it is stipulated that "The system of job classification is made to develop the system of salary and also to promote human resource management and development"[12]. The basis of job qualification system is job catalog of state and municipality institutions. Job catalog is systemized summary of created jobs in the institution. Job catalogue describes job families and subfamilies, standard profiles and a description of basic responsibilities for the corresponding jobs. $T$ he corresponding functions of a job are arranged into functional groups - job families and subfamilies. Job family is the amount of jobs which according to the basic function have similar job tasks and basic responsibilities. Job subfamily is the amount of jobs with narrower but according to the basic function clearly separable specialization. In family and subfamily jobs are divided into levels which describe the main differences between jobs in one family according to the complexity of obligations, responsibility and management functions.

Until the year 2000 in Latvia job descriptions were made and assessed on the basis of regulations "About the intellectual job evaluation and determination of qualification category basic methodology", whereas the evaluation indicator system included such indicators as : A1. Education; A2. Professional experience; B1. Job complexity; B2. Mental strain; B3. Cooperation; C1. Responsibility for the work process and results; C2. Responsibility for decisions [13]. Now this regulation has been divided into two, namely, developing job description in civil service the description of officer's job should be followed, but the new "Regulations about the intellectual job evaluation and determination of qualification category basic methodology for the state budget financed institution employees" [14] are as the basis for the remuneration system.

SRS has divided its activities into three levels - level of objectives, processes and process operations so each task has 
subordinate processes but each process has defined process operations. In this context the authors as a good example would like to mention SRS where, in each employee's job description as the responsibilities of officer, existing process operations have been reflected, which is a very precise definition of job responsibilities for the corresponding job, therefore the content of such document defines entitlement of an officer and what the job description of an officer does not contain, thus it is possible to follow the institutional goal and objective that have to be gained in the corresponding job [15]. This is how the improvements have been obtained in the quality of job descriptions. Within the reorganization of institution SRS avoided inadequate number of customs job positions, such jobs as Customs expert, Customs officer, Junior Customs expert, Junior Customs officer, as a result such jobs as Senior Customs expert and Senior Customs officer were left [16]. One of reasons for selecting such titles after number of SRS Customs reorganizations was higher remuneration ceilings for employees working in Senior positions but not for employees working in "Customs supervisor" and "Customs expert" positions, however this does not influenced responsibilities and job descriptions.

\section{PECULIARITIES OF DEVELOPING JOB \\ DESCRIPTIONS AT THE CUSTOMS AUTHORITIES}

Developing workplace and job descriptions fundamental differences of both terms should be understood which may be mistaken. "Job - official status, post (usually high-level), position (at the institution, company)" and "Workplace adequately equipped and arranged place and environment for performing duties"[17]. As a positive example for respecting the usage peculiarities of both terms is the Latvian SRS, where each employee, apart from the position in institution's organizational structure, occupies a position which has been stipulated in institution's internal instructions, but the term workplace has been found only in the context of customs control point technological chart [18]. The basic principles of developing job descriptions at customs in Latvia are shown in Fig.2.

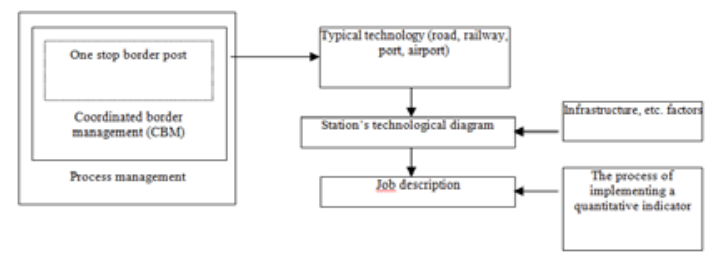

Fig.2.The basic principles of developing job descriptions at customs in Latvia

The aim of standard technologies is to unify and coordinate operational principles of customs, frontier guard and sanitary border inspection in the whole country. Standard technology in the form of description shows the specifics, amount and order of service activities involved in border control. A definite place in work process has been allocated to commercial entities banks and broker companies. In Latvia standard technology has been developed for highway, railroad, port and airport border checkpoints [19]. Each type of customs control point standard technology is influenced by conception of coordinated border management, in some cases one stop border post and process management which are correlated and complementary factors.

The most disruptive obstacles present themselves simply as lack of coordination between government agencies at the border. This lack of coordination leads to poor data sharing, duplicative procedures and a level of inefficiency that results in delays, product deterioration, and overall reduced profitability.

In order to address this degree of disorganization, a country must undertake initiatives to increase interoperability at the border. This interoperability is often referred to as coordinated border management (CBM) or integrated border management (IBM). These terms, while seemingly different, both focus on the same goal: increasing trade efficiency. Increased efficiency improves productivity, reliability, and profitability for all parties involved. Furthermore, to achieve the goal of efficient trade flows across national borders, a country must address pivotal elements of coordination, including, but not limited to, data flow (accumulation, sharing, and dissemination), authority and responsibility at the border, existing trade infrastructure (physical, technological, and organizational), legislation and regulation of border activities, and funding availability for project development.

This process can seem daunting and resource-intensive at times; however, implementing CBM does not need to be complicated and/or expensive. There are many ways to increase border interoperability, from streamlining data flows to developing an electronic single window. CBM is attainable and coordination between agencies is the way forward [20].

It would therefore be the great advantage of a ca refully balanced IBM approach to be able to accommodate the interests of almost all involved at the border: travelers, transporters, border staff and security services. Also for the security concerns of the member states further away from the border, such a mechanism could prove a sufficient safeguard to maintain the trust needed for the open borders of Schengenland [21].

Coordinated border management is the organization and supervision of control activities of border agencies with the aim to perform joint work by facilitating legal movement of passengers and goods at the same time maintaining safe borders and meeting national requirements. Coordinated border management conception consists of two components; the first is inland border management system, which includes coordination of events within one institution and among all one state institutions which are involved in the process of border management, and the second is the international border management system where neighboring countries, customs union member states and trade partners cooperate. As an example of coordinated border management in Latvia is "Interdepartmental agreement about the organization of institution's activities and cooperation at the border crossing points", to ensure "coordinated operations at the border crossing points, where border control, customs control, veterinary inspection, phytosanitary inspection, food safety, quality and classification control have been performed" [22]. More and more emphasis is placed on the second component international "coordination" in cross-border activities. Usually international coordination intends exchange of information 
among customs authorities of different countries. In some cases establishment of one stop border post between neighboring countries is possible. One stop border post is a widespread practice in the world. WCO has grouped this concept as:

- customs control has been carried out in a common territory where both countries' customs institutions are located in one or separate buildings;

- customs control country of export administration carries out customs formalities simultaneously (or almost simultaneously) with country of importation customs administration which can forecast "virtual integration" where border agencies have the responsibility to deal with mutual electronic data transmission to prevent information duplication and to carry out the inspection of passengers and cargoes in the name of other country using mutual recognition regime. Agreement about joint control at merged border posts or one stop border post. Until the accession of Latvia to the European Union (until the year 2004) such agreement was concluded, for example, with Estonia about the establishment of Ainaži - Ikla border post [23]. Basically such agreements are possible only at highway and railway merged border posts, because common border with other country in ports and airports does not exist. Until 1995 joint border control existed between Spain and Portugal [24] typical "Virtual Customs Border Post integration" exists between Norway and Sweden [25].

- international law stipulates sovereignty and the principle of territoriality thus countries have authorities to develop and adjust laws in the area. If special agreements have not been concluded other country's laws and regulations cannot be adjusted automatically. One stop concept implementation stipulates that state institution has to have the possibility to adjust the laws of this country in the territory of other country, in other words, extra territorial jurisdiction should be stipulated [26].

Process - correlated and mutually interacting set of activities which transforms investment into a result. Processes are structured activities which are carried out to do the job and achieve the goal. Primary goal of customs in a traditional model, according to the customs authorities' institutional rating [27], is to increase fiscal revenue, as one of the main functions of customs is to ensure budget revenue, but in the last decade in customs authorities with a traditional institutional model there are two main goals - revenue providing and state security, thus coordinated border management conception has been included in the process management system in its terms.

Customs control point technological chart schematically and descriptively shows the performance specifics, amount and order of each authority involved in customs control point border control. There should be building and site drawings in the annex of technological chart with clearly marked distribution of rooms and area between border control authorities and people who cross border and workplace location [28]. The appearance of each customs control point technological chart depends on the standard technology and infrastructure of customs control point. Workplaces are unified, for example, customs control point technologies of Zilupe, Indra and Kārsava railway station are similar but are not identical with the technologies of highway, airport and port. Highway customs control point technologies of Terehova, Grebṇeva, Pātarnieki and Silene are identical but customs control point Vientulıi differs a little, because the infrastructure of customs border post Vientul,i does not allow to perform certain activities, meaning, it is not properly technically equipped, which has been done at the other external highway points.

Workplace description may be defined as a $\mathrm{r}$ eview of process activities in each workplace. The principles of workplace description development have been schematically shown in Fig. 2. For example at the customs control point Vientuli there are three positions - 1) customs field officer, 2) acceptance of documents (general inspection), execution of documents, correction and issue of documents, 3) physical control of cargoes and vehicles [29]. Depending on the intensity of cargo and passenger flow during a year, a week and a day it is possible to forecast the optimal number of customs officers at the customs control point and thus spread them over workplaces.

The authors conclude that workplaces at customs control point are standard, for example, customs field officer regardless of customs control point type everywhere will be the same, but the position "Physical control" will be different for each type of vehicle - railway, transportation, air and sea transport. Talking about classification of position and other issues of work organization there are two different strictly separated concepts - position of customs field officer and workplace of customs field officer, because in the job description it $\mathrm{m}$ ight be stipulated that duties also in other workplaces have to be done.

\section{THE ROLE OF OCCUPATION STANDARDS IN SATISFACTION OF TRAINING NEEDS}

The research shows main gaps in training provisions managerial and strategic knowledge needs and advanced operational competences. Occupation standard has been created not for the position but for the occupation, so it is important to understand what the occupations for people employed in the customs area are, as over the time the occupation of customs officer has significantly changed (tax and duties collector) and has become the occupation where the knowledge of many fields has to be applied in practice (information technologies, engineering, etc.). First thing that comes into mind to people working at the customs is occupation - customs officer, but during two thousand years, since this occupation was mentioned, the range of customs officer duties has become very diverse, they have to perform jobs of different complexity and degree of responsibility. Not for nothing there is introduced professional qualification which may be divided into levels and which is defined as theoretical and practical qualification which gives the possibility to perform job of certain complexity and degree of responsibility [30]. 
Occupation standard is a document that defines essential requirements of professional qualification, which is needed to perform main tasks in a respective occupation [31]. Occupation standard can be used not only by educators but also by employers, it might be especially useful for human resource managers and specialists who use occupation standards to develop job descriptions and define requirements to applicants for the position corresponding to the occupation, perform profession and functions audits in companies, evaluate positions, create remuneration and employee evaluation system [32]. Creating programs for vocational education, defining goals and objectives of a program as well as the content of subjects and expected results, the information has been obtained from the occupation standard about the things to teach, why teach and what attitudes should be advanced so that the new workforce would correspond to the requirements of the labor market. Professional qualification exam content is worked out on the basis of knowledge and skills indicated in the occupation standard. To ensure and assess quality of vocational education institutions one of the evaluation criterions is theoretical and practical training of vocational education program and qualification practice content conformity to the occupation studied, it is, occupation standard [32]. Within one profession occupation standard includes the necessary information about the requirements of the labor market for employees of corresponding occupation, thus it acts as a tool with the help of which labor market is able to summarize common and specific requirements of industry for a group of employees and hand it in to the educator in a concise form. Occupation standard, in its terms, is an agreement for a specific period of time between employers and educators about the work content of an employee and necessary skills and knowledge.

However, two significant documents in the area of human resource management actually do not interact with each other, meaning, occupation standard development mechanism acts on its own. Of course, educators (internal and external) and top managers from customs authorities are interested in a qualitative customs officer occupation standard but the cooperation mechanism still is not clear.

The authors believe that taking process management system as the basis, where processes would be classified into management processes and key processes which would be divided into control and service processes, it is rational to adjust two qualification levels to the customs officer occupation, namely, ordinary customs officer, who performs operative work and customs manager who not only manages current works but also organizes, plans and manages the work of the department. The World Customs Organization has named occupation standard in English as "Strategic Managers/Leader" and the other as "Operational Managers/Leader" which corresponds to the study program of Riga Technical University "Customs and Tax Administration" professional Bachelor and professional Master's study programs and "Customs authorities' unit manager" occupation standard in Latvia. Taking peculiarities of potential process division at customs authorities and professional qualification division as a basis the authors offer new approach to the principles of occupation standard development at customs authorities, namely, the occupation "Customs expert" has occupation standard which is at a lower level of qualification than occupation "Customs authorities' unit manager" or "Operational Managers/Leader"[33] occupation standard. It would be substantial to assure if the customs operational side would be included in customs expert occupation standard or key process service and control processes. The authors can affirm that there can be no dispute among workers at the customs authorities on the issue if the manager of a department needs to manage operational work or not. Therefore occupation standard "Customs authorities' unit manager" will stipulate to know key processes with control and service processes and management processes which will determine other level occupation standard. See Fig.3.

It may be concluded that it would be useful in any country to stipulate also single occupation standards for entrepreneurs who fully or partly base their business providing services in customs area and those would be customs brokers, declarants, economic operators or differently named occupations depending on the delegated authorities of corresponding country to provide services or work in the area.

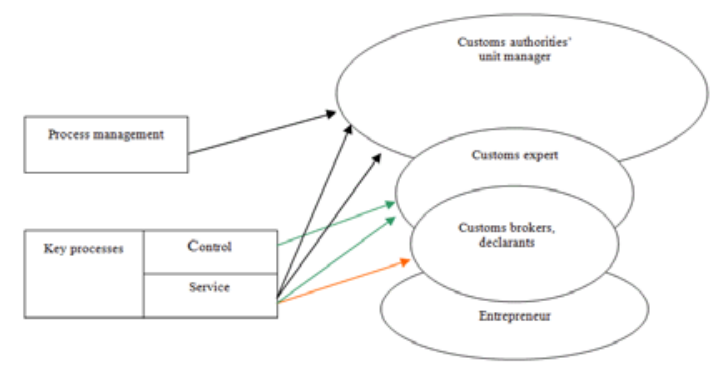

Fig.3.Principles of occupation standard development according to the process management

See Fig.3. The authors would like specially to emphasize that entrepreneurs should know the service processes of customs authorities in the same amount, quality and even interpretation as customs officers, but it would not be acceptable to know the control processes, because the control is the function only of customs authorities. Therefore establishing the necessary occupation standard for the employees working in the customs area it is expected to have a good knowledge of business and partly customs area.

\section{CONCLUSIONS}

Synchronization of occupation standards both of service providers in the customs area and customs profession may promote labor market inclusion for customs officers. Thus created single education process based on occupation standards would allow providing system mobility and convergence.

Development of occupation standards ensures the possibility for training providers to act according to the needs of TCA as an employer, which arise from the goals and objectives of an employer, it is exactly the same as the job descriptions are made according to the goals and objectives of an employer, in occupation standards and job descriptions should be included section "responsibilities", thus the authors do not see any problems defining responsibilities in both 
documents, define them equally according to the processes. The same applies to the sections "knowledge" and "skills". Occupation standard should be very flexible document, which together with the job description would react to the changes as soon as in the occupation standard and in any of the customs officer's job descriptions change section "responsibilities", there is a change in occupation standard section "knowledge" and "skills", changes also corresponding customs officer's section "knowledge" and "skills", so it is a real mechanism how to determine the circle of those employees who would need new "knowledge" and "skills" performing direct duties. Thus it would be as an indicator to recognize if a representative from customs profession is needed in a certain position or a person from other profession.

Synchronizing requirements on selecting employees, evaluating their compliance to the position, assessing their performance in a definite period of time, developing training programs in a professional level of education and in the issues concerning further professional education, everybody, human resource management specialists and managers from customs authorities, has to act according to the same identically formulated indicators - knowledge and skills.

\section{REFERENCES}

[1] E.Vacík, L. Zahradníčková, "Process Perfromance- A Significant Tool of Competitiveness of Enterprises in Contemporary Era", Proceedings of the 10th International Conference Liberec Economic Forum 2011, Liberec, Czech Republic, ISBN 978-80-7372-755-0.

[2] F.Rivas-Echeverría, Lifelong Learning: A Dream that Unites the World and the Mission of Universities in ItsImplementation http://www.wseas.us/e-

library/conferences/2013/Malaysia/EDUETE/EDUETE-00.pdf, viewed 20.08.2013.

[3] [A.Jakobsone, S.Cakula, Information Flow Modeling to Provide Sustainable Cooperation between Educational Institutions and Entrepreneurs, $\quad$ http://www.wseas.us/elibrary/conferences/2013/CambridgeUSA/EET/EET-14.pdf, viewed 20.08.2013.

[4] Welcome to PICS, https://webgate.ec.europa.eu/pics/welcome , viewed 24.03.2012.

[5] R.Jovaišienè PROBLEMS OF LITHUANIA CUSTOMS OF CHANGES JOB QUALIFICATION REQUIREMENTS FOR LITHUANIA CUSTOMS OFFICERS IN MANAGEMENT STRATEGY (LIETUVOS MUITINĖS PAREIGŪNŲ PAREIGYBIŲ KVALIFIKACINIŲ REIKALAVIMŲ NUSTATYMO PROBLEMATIKA, LIETUVOS MUITINĖS POKYČIŲ VALDYMO STRATEGIJA), Vilnius, Jurisprudencija, 2003, vol.48(40), pp.33-45 .

[6] B. Prepelita-Raileanu, Education, Research and Business a Knowledge Triangle and a S trategic Partnership between Technical Academic Research and Romanian Business Community http://www.wseas.us/elibrary/conferences/2011/Corfu/EDUC/EDUC-43.pdf, viewed 20.08.2013.

[7] Guidelines for the State Revenue Service department process optimization and their performance and cost accounting (Vadlīnijas Valsts ien̦ēmumu dienesta struktūrvienību procesu optimizēšanai un to izpildes un izmaksu uzskaite), State Revenue Service, 1 November, 2011 order No.3260), unpublished.

[8] Annual reports (gada pārskati), http://www.vid.gov.lv/default.aspx?tabid $=4 \& \mathrm{id}=8 \& \mathrm{hl}=1, \quad$ viewed 20.08.2013.

[9] State Civil Service Law (Valsts civildienesta likums), Law was adopted in Saeima on September 7, 2000, http://www.likumi.lv/doc.php?id=10944, viewed 23.02.2013.
[10] Labor Law (Darba likums), Law was adopted in Saeima on June 20, 2001, http://www.likumi.lv/doc.php?id=26019, viewed 23.02.2013.

[11] Procedures for developing job description of civil servant (Ierēdņa amata apraksta izstrādāšanas kārtība), The Cabinet of Ministers of the Republic of Latvia instruction No. 5, Riga, December 5, 2000 (prot. No.57 10.§), http://www.likumi.lv/doc.php?id=13429\&from $=$ off,$\quad$ viewed 23.02.2013.

[12] Posts catalog of state and municipality institutions (Valsts un pašvaldību institūciju amatu katalogs), The Cabinet of Ministers regulations No. 1075, Riga, November 30, 2010 (prot. No. 69 55.§), http://www.likumi.lv/doc.php?id=222271, viewed 23.02.2013.

[13] Regulations on determination methodology of intellectual work evaluation and qualification categories (Noteikumi par intelektuālā darba novērtēšanas un kvalifikācijas kategoriju noteikšanas pamatmetodiku), The Cabinet of Ministers regulations No. 185, http://www.likumi.lv/doc.php?id=40439, viewed 23.02.2013.

[14] Regulations on determination methodology of intellectual work evaluation and qualification categories for government funded institution employees (Noteikumi par intelektuālā darba novērtěšanas un amatu kvalifikācijas kategoriju noteikšanas pamatmetodiku no valsts budžeta finansējamo institūciju darbiniekiem), The Cabinet of Ministers regulations No. 533, Riga, September 23, 2003, (prot. No.50 25.§), http://www.likumi.lv/doc.php?id=79305, viewed 23.02.2013.

[15] Pētersone, M. Features of Process Management in Customs. In: Create future: Communication, education, business: XIV international scientific conference, Latvia, Riga, 30-30 May, 2013. Riga: "Business school Turība" Ltd, 2013, pp.209-220. ISSN: 1691-6069.

[16] Classification of Occupations 1st supplement (Profesiju klasifikators1.pielikums), The Cabinet of Ministers regulations No. 461, $\begin{array}{lll}\text { May 2010, } & \text { 18, }\end{array}$ http://www.lm.gov.lv/upload/darba_devejiem/profesiju_klasifikators2.p df, viewed 06.03.2013.

[17] I. Bel̦ickis, D. Blūma, T . Koke, D. Markus, V. Skujina and A. Šalme, Explanatory dictionary of pedagogical terms (Pedagogijas terminu skaidrojošā vārdnīca), Riga, Zvaigzne ABC 2000., ISBN 9984-17-686-X

[18] SRS CA job description of customs post "Vientuļi”, department of Latgale 0712 (VID MP Latgales MKP daḷas „Vientul̦u” MKP 0712 darba vietu apraksts), 01.03.2010.

[19] M. Pētersone, The basic principles of developing job descriptions at customs (Darbavietu apraksta veidošanas pamatprincipi muitā), RTU Scientific Literary Works, Business and Management, part 3 Economics and Management, 2001.

[20] K. Elmane-Helmane, K. Ketners. INTEGRATED CUSTOMS CONTROL MANAGEMENT IN LATVIA: LESSONS LEARNED. ECONOMICS AND MANAGEMENT, 2012.vol. 17(2), 528-533.

[21] P. Hobbing Integrated Border Management at the EU Level. CEPS Working Documents No. 227, 1 August 2005.

[22] Interdepartmental agreement on the organization of institution's activities and cooperation at the border crossing points (Starpresoru vienošanās par iestāžu darbības un sadarbības organizēšanu robežšksērsošanas vietās), 17.04.2012., unpublished.

[23] Temporary Technological scheme of joint border control at the joint border checkpoints Ainazhi-Ikla, Annex to the Agreement, the Customs Department of the Republic of Estonia, the Border Guard of the Republic of Estonia and the Customs Office of the Republic of Latvia, the Latvian Border Guard of the Republic of joint control of a joint border checkpoints Ainazhi - Ikla (Временная технологическая схема совместного пограничного контроля на совместном пограничном контрольном пункте Аинажи- Икла, Приложение к Соглашению Таможенного департамента Эстонской Республики, Департамента пограничной охраны Эстонской Республики и Таможенного Управления Латвийской Республики, Пограничной Охраны Латвийской Республики о совместном контроле на совместном пограничном контрольном пункте Аинажи- Икла), 1999, unpublished.

[24] E. J. R. Medeiros, Old vs recent cross - border cooperation: PortugalSpain and Norway-Sweden. Area, 2010, vol.42(4), pp.434-443, DOI: 10.1111/j.1475-4762.2010.00940.x, viewed 25.06.2013. 
[25] A.Hellberg, Coordinated Border Management, Picard, 2011.Prezent. mater.

[26] E.Kieck, Coordinated border management: unlocking trade opportunities through one stop border posts, http://worldcustomsjournal.org/media/wcj/-2010/1/Kieck.pdf, viewed 20.02.2013.

[27] Pētersone, M., Ketners, K. Institutional Division of Customs Administrations. In: Production and Cooperation in Agriculture. Finance and Taxes: Proceedings of International Scientific Conference "Economic Science for Rural Development", Latvia, Jelgava, 25-26 April, 2013. Jelgava: Latvian University of Agriculture, 2013, pp.207213. ISBN 9789934830464.

[28] Standard technology of border guards and customs at the highway border posts (Robežapsardzes un muitas darbïbas tipveida tehnologija autoceļu robežkontroles punktos), Project 08.03.1999. ,unpublished.

[29] State Revenue Service Customs Administration job description of customs post "Vientulili", department of Latgale 0712 (Valsts ien̦ēmumu dienesta Muitas pārvaldes Latgales MKP daḷas „Vientuḷu” MKP 0712 darba vietu apraksts), 01.03.2010, unpublished.

[30] M.Pētersone, A. Krastiņš The role of occupation Standard in establishment of customs officer coordinated professional development and training system (Profesiju standarta loma koordinētas muitnieku profesionālās izaugsmes un apmā̄īibas sistēmas izveidē), RTU Scientific Literary Works, part 3 Economics and Management - vol. 22, 2012, pp. 139.-143.

[31] Vocational Education Law ( Profesionālās izglītības likums), http://www.likumi.lv viewed 20.01.2012.

[32] Professional standards development methodology (Profesijas standartu izstrādes metodika), http://visc.gov.lv [tiešsaiste], viewed 01.02.2012.

[33] Professional standarts, http://incu.org/docs/WCO PICARD_Professional_Standards.pdf, viewed 15.03.2013.

\section{Creative Commons Attribution License 4.0 (Attribution 4.0 International, CC BY 4.0)}

This article is published under the terms of the Creative Commons Attribution License 4.0 https://creativecommons.org/licenses/by/4.0/deed.en US 